\title{
A Conceptual Framework to Measure Economic Growth of Afghanistan
}

\author{
Sayed Ramez \\ Postgraduate Center \\ Limkokwing University of Creative Technology \\ Malaysia \\ Muhammad Farooq (Corresponding author) \\ Postgraduate Center \\ Limkokwing University of Creative Technology \\ Malaysia \\ Valliappan Raju \\ Postgraduate Center \\ Limkokwing University of Creative Technology \\ Malaysia
}

Received: December 4, 2018 Accepted: December 15, 2018 Published: January 13, 2019

doi:10.5296/jad.v5i2.14210

URL: https://doi.org/10.5296/jad.v5i2.14210 
Abstract

Afghanistan is the least developed country in Asia which is under war from the previous 20 years. After the end of the partial war, many aspects of Afghan economy are improving, for instance, the GDP has advanced 2.5\% from 2016 to 2017. However, Per Capita Income is very low, safety, health and education are the areas which needs improvement. The exports of Afghanistan are on the decline. The natural currency reserve of Afghanistan is decline despite having many mineral assets. One of the core apparent behind all these decline aspects is corruption in Afghanistan. As transparency international the corruption of Afghanistan has increased in 2017 compared to 2016. It is of the most corrupt countries in the world. Due to war and less developments Afghanistan is least studied country. To fill this gap in this study the research has explored multiple secondary data source to review existing economic situation in Afghanistan. After exploring the economy of afghanstan the study also provides a conceptual framework for future reseachers to review economic growth of afghanistan using given framework. The study is useful for the policy makers to improve policies and prosperity of the country by identifying the role of crime.

Keywords: Economic Development, Corruption, Inflation, Afghanistan, GDP

\section{Introduction and Background}

Economic development is the method by which a state progresses. It includes the commercial, political, and societal welfare of its public. The term economic growth has been used recurrently by economists, bureaucrats, politicians, and others in the 20th and 21 st centuries. This concept widely used all over the world (Lembo Tanning, 2014; Eiilm university, 2018). Advancement in technology led to more awareness and well-informed public across the globe (Farooq \& Jabbar, 2014; Buzdar, Janjua and Khurshid, 2016; Farooq et al., 2018; Khalil-ur-rehman \& Farooq, 2018). Due to the involvement of so many stakeholders in economic development has different types of definitions in different context. As per one of the well-known professors of Economics and public policy in Michigan university Professor Deardorff leconomic development is "Sustained increase in the economic standard of living of a country's population, normally accomplished by increasing its stocks of physical and human capital and improving its technology.". In terms of context when its related to urban areas the economic development means jobs, community property and sale base expansion, retail and industry development in the metropolitan area. In all the world especially in the developed world, the quality of life is linked to economic development. Economic and business developers in united states immensely realize the importance of economic growth to improving the quality of life. Quality of life includes ecological, recreational activities, social infrastructure, child care, the safety of the people in doing all type of business and security of health and wealth. These benefits of economic development make the development pivotal for any country.

In the developed world mainly in USA and Europe, there is political stability, which is creating a better quality of life and growing their economy. In the developing world, in countries like India, Bangladesh and Pakistan things are getting better because of not having any major war and politics is also getting stable. In Asia mainly, Afghanistan is the most 
vulnerable country. Current situation of Afghanistan is better compared to its position 10 years ago. There are many factors which are keeping Afghanistan backward but one of the core issues as listed by transparency international it's of the most corrupt countries in the world. Out of 180 registered, it's among the top five corrupt countries as shown in table.1. There are very few studies conducted before on the role of corruption in the economic development of Afghanistan. The earlier held studies were done many years ago. The recent situation of Afghanistan has changed. Afghanistan will have very soon elections in 2018 which means progress towards democracy, political stability, and economic growth chances will rise. Hence this study has focused on the role of corruption in the economic development of Afghanistan (McCranie et al., 2011).

\section{Literature Review and Materials}

This study is focused on introducing a new perspective on the role of corruption in economic growth and provides quantitative estimates of the impact of corruption on the growth and importance of the transmission channels. In the previous studies conducted in this area, the simple technique of ordinary least squares estimations were used, the authors identified that a $1 \%$ increase in the corruption level reduces the growth rate by about $0.72 \%$ or, expressed differently, a one-unit increase in the corruption index reduces the growth rate by 0.545 percentage points. The most critical channel which was found by earlier research was through which corruption affects economic growth is political instability, which accounts for about $53 \%$ of the total effect. Mo (2001) also find that corruption reduces the level of human capital and the share of private investment. (Mo, 2001)

Corruption is a disingenuous weapon; its presence perpetrates significant economic costs on an economy. Corruption reduces both the volume and efficiency of investment and thus economic growth. This note identifies a simple concept of the macroeconomic effects of financing, establishes its linkage with corruption and estimates the relationship between them. The efficiency of investment variables computed by the authors and Transparency International's Corruption Perception Indices are used as data. In the literature, the authors conclude that substantial gains in terms of economic growth could be achieved if corruption is reduced (Avnimelech \& Zelekha, 2015)

In Vietnam, regardless of the Government's recognition of the severe threat of uncontrolled crime to the legitimacy and long-term survival of the current political system, Vietnam is still struggling to translate its policies and comparatively strong legislative framework into practice. There exists little reliable, quantitative evidence of the harmful impact of corruption on economic growth in Vietnam. Using the most updated and available data and a model incorporating transmission channels, this article attempts to estimate the direct and indirect effects of corruption on GDP growth rate. In general, the findings confirm the negative association between crime and economic growth. The investment appears to be the most critical transmission channel and the effect of corruption on investment is non-linear so that indirect impacts of corruption on growth (via investments) depends on the value of each country's corruption level. In case of Vietnam, a one unit increase in the corruption perception index (CPI) 1 leads to a $2.15 \%$ increase in the proportion of gross domestic 
investment over GDP, which in turns increases growth rate by $0.372 \%$. Counting both direct and indirect effects, a one-unit increase in the corruption perception index (CPI) will increase the growth rate by $0.509 \%$, indicating that the investment channel accounts for $62.92 \%$ of total effects. (Sarkar \& Hasan, 2001; Mo, 2001; Avnimelech \& Zelekha, 2015)

The impact of corruption on Afghanistan has been validated from the earlier studies conducted in Mediterranean countries, during the period from 2000 to 2018. Mainly in these studies, econometric analysis using panel regression has been adopted to test this effect. Individual effects models such as the random effects model and fixed effects model were applied to the study sample and collected observations. we implemented several tests. For our analysis, we used a basic model that includes the dependent variable GDP per capita as a factor of economic growth and the corruption perception index as the independent variable concerned. Then we completed the model with several standardized macroeconomic control variables mentioned above and applied the individual effects models. The outcomes illustrate that corruption has a negative impact on the selected Mediterranean countries' economic growth (Boussalham, 2018).

Corruption in Afghanistan has developed, broadly predictable as a critical encounter for supremacy and the rule of law and as an impediment for sustainable, private-sector-led economic growth, says the Centre for International Private Enterprise (CIPE). The Afghan government has made several commitments to address corruption at previous conferences and within the scope of the Afghan National Development Strategy (ANDS). However, the problem is still widespread, according to major non-governmental organizations (NGOs) (Eray Basar, 2012). This research addresses the economic costs which are associated with corruption in Afghanistan. Besides the mean the role of crime this study has also investigate essential aspects of Accountability of government spending and the growing emphasis on anti-corruption in Afghanistan justify this study. The core objective of the study was to identify the factors which are causing low economic growth in Afghanistan and recommend a course of action to responsibly and systematically reduce corruption and to improve the economy. The study has examined both advantageous and disadvantageous effects of corruption using theory, as well as empirical analyses of crime on transnational countries facing similar levels of perceived corruption and economic development levels. Evaluation of factors associated with economic growth and corruption levels from 2005 to 2010 determine which corruption theories apply best to Afghanistan. The results indicate that increased corruption levels have resulted in a decline of the gross domestic product of some 87 percent from 2005 to 2010. Afghanistan also experienced an increase in the level of corruption and inflation in this period

\section{Introduction of Afghanistan}

Afghanistan is a southern Asian least developed country among developing counties in Asia. It's located in north and west of Pakistan and east of Iran. It has mostly rugged mountains, grasslands in south and southwest. Afghanistan is blessed with a lot of natural resources because of having peaks and plan areas. It has Coal. Natural gas, Copper, Petroleum, Barites, talc, arable land, precious and semiprecious stones, salt, Iron ore, lead, sulfur, and Zinc. 
Despite having so many resources, Afghanistan has $58.1 \%$ of its territory as agricultural land which is spread over the west of Afghanistan mainly. still, Afghanistan is struggling for political stability and security situations. There is uncertainty in the country which is leading towards unethical activities like corruption. Most of the population in Afghanistan is Muslims.99.7\% population in Afghanistan is Muslims, and only $0.3 \%$ are other religious people.

\subsection{Population Dynamics in Afghanistan}

Afghanistan has an extremally well-desired population in terms of age which every country would like to have. In total population of Afghanistan 40.92\% (male 7,093,980/female $6,869,737)$ which are $40.92 \%$ of overall population. This segment is highest in the count in the world. From the age of $15-24$ count is $22.2 \%$ which is also very much a desirable amount of young people. In the second segment out of $22.22 \%$, the male 3,859,696 are, and female is $3,723,679$. The third segment which is the second largest segment after children is the count of people ranging from 25-54. In 25-54 age there are 30.35\% people in Afghanistan, (male $5,273,969 /$ female 5,082,972). Due to continues wars in Afghanistan in the last 50 years, the segment which has least count is 55 years old segment. Only 6\% population is $55+$ in Afghanistan. In economy point of view, this is a very desirable count. Despite having a good economy, there is another economical and population highlight which is the dependency ratio. The total dependency of the Afghan population is 88.8 , which means $88.8 \%$ of people are dependent on $11.2 \%$ people. Similarly, in the youth segment, the dependency ratio is $84.1 \%$, which means $84 \%$ of youth is not working. In the eldest segment, the count of people who are dependent is also high. As most of the people in Afghanistan are young. The median age of the population is 18.8 in which females are on average 18.9 and men are on average 18.8 years old. In world ranking, it's the $207^{\text {th }}$ country in the world in terms of having the age of the people. The growth rate of population in Afghanistan is very high. With $2.36 \%$ of growth rate, it's the world $29^{\text {th }}$ growing country. The primary factor which is leading the growth rate is the birth rate. The birth rate in Afghanistan is 37.9births/1000 people, which makes it top $10^{\text {th }}$ country in terms of growth rate. Despite all these factors, Afghan people are loyal to their country. The percentage of immigration is meager, and it was recorded $-0.9 \%$ per 1000 person in 2017 which makes 134 countries on the world map in terms of immigration (CIA-World Factbook, 2018).

Another exciting reason to study Afghanistan and its economic growth is the distribution of the population. Only $25.5 \%$ of the population is the urban population in Afghanistan. The growth rate in urbanization is $3.37 \%$. Another reason to study Afghanistan is the lower hygiene and health rated issues. In Afghanistan, birth among women happens at the age of 19.9 years on average. Due to being the war victim area and internal conflicts the maternal death rate is also high, the death rate per 1000 women on maternity is 396 which makes it world $28^{\text {th }}$ country. The factor in health makes Afghanistan must study and grow state is the infant mortality rate. In infant mortality rate it's the world number one country. In Afghanistan on average out 1000 births 110.6 deaths happen. The number is Hight for the male which 118 out of 1000 while for females it's 102.9. Because of continuous wars and internal conflicts in Afghanistan the life expectancy at birth is only 51.7 years. The likelihood 
of a male is lower due to war issues which are 50.3 while for females the possibility is $53.2 \%$. Despite this issue, total fertility per women is 5.12 which makes Afghanistan of the high fertility rate countries. The government spends least the on the health. Only $8 \%$ of GDP is spent on health. The count of physicians is the lowers in the world which is 0.3 out 10000 people. Being an underdeveloped and mountain areas country, Afghanistan does not have any obesity issues among its people. The obesity rate in Afghanistan is only 5.5\%. On world map in terms of obesity Afghanistan is on $177^{\text {th }}$ position.

\subsection{Health and Education Dynamics in Afghanistan}

One interesting fact which can be the possible reason behind keeping Afghanistan backward is less focus on education. These are the least focus on training which can be observed in the budget allocation of the country. Only $3.2 \%$ of the GDP is the education spending. As per the definition of literacy rate which is that "The age 15 and above can read and write" in the Afghan population only $38.2 \%$ people are educated. The education ratio is male is comparatively high then females. $52 \%$ male is educated while in women only $24.2 \%$ are educated. Most of the students do not survive in the school. The average years in which one Afghan young adult stay in education or in school is 11 years. For males, it is 13, for females its only 8 years. Knowledge can be of the critical factors of studying the economic growth in Afghanistan (CIA-World Factbook, 2018).

\subsection{Life in Afghanistan}

Despite improvements in life expectancy, incomes, and literacy since 2001, Afghanistan is extremely poor, landlocked, and highly dependent on foreign aid. Much of the population continues to suffer from shortages of housing, clean water, electricity, medical care, and jobs. Corruption, insecurity, weak governance, lack of infrastructure, and the Afghan Government's difficulty in extending the rule of law to all parts of the country pose challenges to future economic growth. Afghanistan's living standards are among the lowest in the world. Since 2014 , the economy has slowed, in large part because of the withdrawal of nearly 100,000 foreign troops that had artificially inflated the country's economic growth (CIA-World Factbook, 2018).

The international community remains committed to Afghanistan's development, pledging over $\$ 83$ billion at ten donors' conferences between 2003 and 2016. In October 2016, the donors at the Brussels conference pledged an additional $\$ 3.8$ billion in development aid annually from 2017 to 2020. Even with this help, Government of Afghanistan still faces the number of challenges, including low revenue collection, anemic job creation, high levels of corruption, weak government capacity, and poor public infrastructure (CIA-World Factbook, 2018).

\subsection{The Economic Situation in Afghanistan}

In 2017 Afghanistan's growth rate was only marginally above that of the 2014-2016 average. The drawdown of international security forces that started in 2012 has negatively affected economic growth, as a substantial portion of commerce, especially in the services sector, has catered to the ongoing international troop presence in the country. Afghan President Ashraf 


\section{Macrothink

GHANI Ahmadzai is dedicated to instituting economic reforms to include improving revenue collection and fighting corruption. The government has implemented improvements to the budget process and in some other areas. However, many other changes will take time to perform, and Afghanistan will remain dependent on international donor support over the next several years.

The most important indicator of economic growth of any country is its Gross Domestic Product (GDP) of the country. GDP of Afghanistan has improved in last three years. Blow table-3 shows the progress in GDP of Afghanistan. Compared to its population the GDP is very low, but it's on track now. Table-2 shows the GDP growth rate of Afghanistan

\subsection{GDP Growth in Last 3 Years}

After the end of the war (although still, US troops are present in Afghanistan there is an Afghan government in Afghanistan now) the GDP of Afghanistan has improved. It has improved from 67.07 Billion to 69.55Billion per year. The table below shows the in detail the increase in GDP in Afghanistan.

- $\$ 69.55$ billion (2017 est.)

- $\$ 67.94$ billion (2016 est.)

- $\$ 67.07$ billion (2015 est.)

Note. Data are in 2017 dollars.

Source: (CIA-World Factbook, 2018).

\subsection{GDP - the Real Growth Rate}

In the last three years GDP of Afghanistan has increased from $1.3 \%$ to $2.5 \%$. Although the count of increase is very less, it's increasing which shows a better future for Afghanistan.

\section{$2.5 \%$ (2017 est.)}

$2.4 \%$ (2016 est.)

$1.3 \%(2015$ est.)

Note. Country comparison to the world: 133.

Source: (CIA-World Factbook, 2018).

\subsection{GDP - Per Capita (PPP)}

GDP per capita has decreased. It has decreased from 2100 to 2000 US dollars. In terms of per capita GDP improvement, there is a lot of improvement required. This factor can help us in the study to identify the GDP per capita role in corruption. In GDP per capita, Afghanistan is at $207^{\text {th }}$ position.

$\$ 2,000$ (2017 est.)

$\$ 2,000$ (2016 est.) 
$\$ 2,100$ (2015 est.)

Note. data are in 2017 dollars

Country comparison to the world: 207

\subsection{Gross National Saving}

Savings of Afghanistan has decreased in last three years. Below table shows the saving history and amount in the last three years in detail.

$19 \%$ of GDP (2017 est.)

$25.5 \%$ of GDP (2016 est.)

$25.9 \%$ of GDP (2015 est.)

Note. Country comparison to the world: 102.

3.8 GDP - Composition, by End Use

GDP composition by the end user is very less which highlights the corruption.

\begin{tabular}{|l|}
\hline household consumption: $81.6 \%$ \\
\hline government consumption: $12 \%$ \\
\hline investment in fixed capital: $17.2 \%$ \\
\hline investment in inventories: $30 \%$ \\
\hline exports of goods and services: $6.7 \%$ \\
\hline imports of goods and services: $-47.6 \%$ (2016 est.) \\
\hline
\end{tabular}

\subsection{GDP - Composition, by Sector of Origin}

As 58\% land of Afghanistan is agriculture, so their main source of income and main contribution in the economy is coming from the agriculture. Agriculture constitutes $23 \%$ of the economy, and the industry is providing only $21.1 \%$. The service sector is the largest contributor who is almost $60 \%$.

agriculture: $23 \%$

industry: $21.1 \%$

services: $55.9 \%$

Note. Data exclude opium production (2016 est.)

\subsection{Agriculture - products}

Afghanistan is very due to the production of opium, wheat, fruits, nuts, wool, mutton, 


\section{Al Macrothink}

sheepskins, lambskins, poppies

\subsection{Industries}

The industries which are operating in Afghanistan are the small-scale production of bricks, textiles, soap, furniture, shoes, fertilizer, apparel, food products, non-alcoholic beverages, mineral water, cement; handwoven carpets; natural gas, coal, copper

\subsection{The Industrial Production Growth Rate}

Despite having so many industries the growth rate of industries in declining as per the available states- $1.9 \%$ (2016 est.)

\subsection{Labor Force}

Afghanistan population mainly con,constitutes the young people. As per 2017 estimates, it has 8.478 million (2017 Est) the country ranking worldwide is 62

Labor force - by occupation

$58 \%$ of Afghanistan land is agriculture; therefore people are mainly skilled in agriculture.

\begin{tabular}{|c|c|}
\hline Contributors & $\%$ of contribution \\
\hline Agriculture & $44.3 \%$ \\
\hline Industry & $18.1 \%$ \\
\hline services & $37.6 \%$ \\
\hline
\end{tabular}

\subsection{Unemployment Rate}

Due to improvement in overall GDP, the unemployment rate in Afghanistan is reducing

\begin{tabular}{|c|c|}
\hline Year & Percentage \\
\hline $\mathbf{2 0 1 7}$ & $23.9 \%$ \\
\hline $\mathbf{2 0 1 6}$ & $22.6 \%$ \\
\hline
\end{tabular}

The country in comparison of world countries stands on $193^{\text {rd }}$ position, which means the unemployment is very high. The poverty in the country is also high. 54.5\% (as per 2017 est.) of the population is below the poverty line. 
3.15 Household Income or Consumption by Percentage Share

Household income statists of Afghanistan are not at the required level which needs studying Afghanistan.

\begin{tabular}{|c|c|}
\hline Household Income & Percentage \\
\hline Lowest $\mathbf{1 0 \%}$ & $3.8 \%$ \\
\hline Highest $\mathbf{1 0} \%$ & $24 \%$ \\
\hline
\end{tabular}

Budget: The expenditures of Afghanistan are higher than its earning. Which is leading to loss of the economy, account deficit and loan from the external countries.

\section{Revenues of 2017 estimated $=\$ 2.276$ billion}

\section{Expenditures 0f 2017 estimated $=\$ 5.328$ billion}

\section{Taxes and other revenues}

Tax collection statistics of Afghanistan are satisfactory keeping in view the political and economic situation. $10.8 \%$ of GDP (2017 est.) constitutes from tax and other sources of income.

\subsection{Budget Surplus (+) or Deficit (-) \\ $-14.5 \%$ of GDP (2017 est.)}

Due to the high expenditure, the deficit is high, for which the main reason is corruption

\subsection{Public Debt}

Afghanistan has reduced its public debt in 2017, despite reduction in debt it is still on 201st position.

Estimated in 2017: $7.3 \%$ of GDP

Estimated in 2016: $8 \%$ of GDP

\subsection{Inflation Rate (Consumer Prices)}

An inflation rate of Afghanistan has increased in 2017. In the world it's on $174^{\text {th }}$ position in terms of inflation rate

Estimated in $20175 \%$

Estimated in 2017: 4.4\%

3.19 Commercial Bank Prime Lending Rate 
Commercial banks are lending amount remained the same in 2016 and 2015. Compared to rest of the world countries it's in $46^{\text {th }}$ position.

Estimated in 2016: $15 \%$

Estimated in 2015: 15\%

\subsection{The Stock of Narrow Money}

Stock for small money in Afghanistan improved in 2014. It is ranking as 2014 last available report is 92 .

Estimated in 2014: \$6.644 billion

Estimated in $2013 \$ 6.192$ billion

\subsection{The Stock of Broad Money}

The Stock for bond money in Afghanistan improved in 2014. It's ranking as 2014 last available report is 117 .

Estimated in 2014: $\$ 6.945$ billion

Estimated in 2013: $\$ 6.544$ billion

\subsection{Current Account Balance}

Currently account balance of Afghanistan has increased in 2017, in terms of current account its world $56^{\text {th }}$ country.

Estimated in 2017: \$328 million

Estimated in 2017 \$1.372 billion

\subsection{Exports}

Despite other indicators improvement Afghanistan could not improve its exports one of the reason of not increasing the exports is increased corruption. It still has a long way to improve its exports. In world it's ranking on the 171th country in the amount in which it sends exports to the world. The export commodities of Afghanistan are opium, Fruits and nuts, handwoven carpets, wool, cotton, hides and pelts, precious and semi-precious gems and medical herbs. The main countries which buy exports of Afghanistan are Pakistan and India. India buys 57\% of Afghanistan exports, the rest of the exports which 30\% are brought by Pakistan.

Estimated in 2017: \$784 million

Estimated in 2017: \$614.2 million

\subsection{Imports}




\section{Macrothink}

Journal of Asian Development

ISSN 2377-9594

2019, Vol. 5, No. 2

Despite the fact that the decrease in exports imports of Afghanistan has increased. It stands in $109^{\text {th }}$ position in the world in terms of imports.

Estimated in 2017: $\$ 7.616$ billion

Estimated in $2016 \$ 6.665$ billion

\subsection{Imports - Commodities}

Machinery and other capital goods, food, textiles, petroleum products

Imports - partners

Goods are mainly imported from China, Iran, and Pakistan. Below table explains the imports country.

$21 \%$ of goods are imported from China

$20.5 \%$ of goods are imported from Iran

$11.8 \%$ of goods are imported from Pakistan

$11 \%$, of goods are imported from Kazakhstan

$6.8 \%$ of goods are imported from Uzbekistan

$5.3 \%$ of goods are imported from Malaysia

\subsection{Reserves of Foreign Exchange and Gold}

Country reserves if Afghanistan has increased from 6.901 billion in 2016 to 7.405 billion in 2016.

Estimated as of December 2016: $\$ 7.405$ billion

Estimated as of December 2015: \$6.901 billion

$85^{\text {th }}$ country in world ranking

3.27 Debt - External

\$2.84 billion (FY 10/11)

$\$ 2.823$ billion (FY 10/11)

$144^{\text {th }}$ country in world countries comparison 


\section{Macrothink}

\subsection{Exchange Rates}

Afghanistan (AFA) per US dollar compared to the US Dollars

Estimated in 2017: 7.87 compared to US Dollar

Estimated in 2017: 68.03 compared to US Dollar

Estimated in 2017: 67.87 compared to US Dollar

Estimated in 2017: 61.14 Compared to US Dollar

Estimated in 2017: 57.25 Compared to US Dollar

\subsection{Corruption in Afghanistan}

Corruption is of the key issues in Afghanistan as shown in the above statistics. Afghanistan is on $177^{\text {th }}$ position in corruption. Blow diagram shows that Afghanistan is $5^{\text {th }}$ position in the world in corruption.

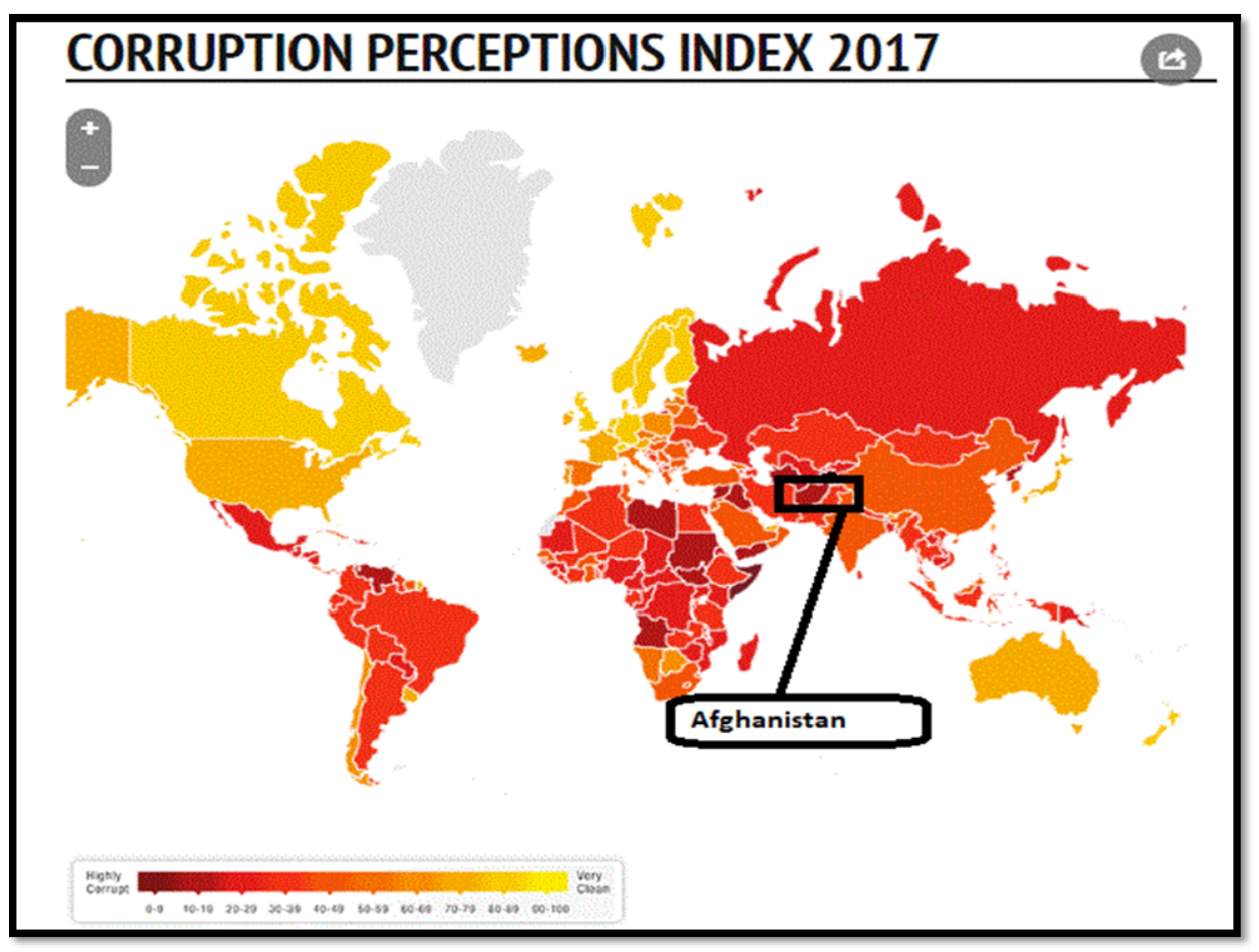

Figure 1. Corruption Index 2017

\section{Conceptual Framework}

Based on the literature key statistics of the economy, future researchers can study the below Figure-2 conceptual framework. The corruption Index from well know organizations like transparency international, growth or decline in exports, the investments which are made in the country, per capita income, Country reserves, Human index (spending on human 


\section{Macrothink Institute ${ }^{\mathrm{TM}}$}

resources) and budget priorities are the areas which future researches can study to review the economic growth in Afghanistan. For any problem resolution instead of treating the symptoms it is recommended to focus on the root cause of the problem (Farooq, 2019). This conceptual framework addresses the root cause to develop economy of Afghanistan.

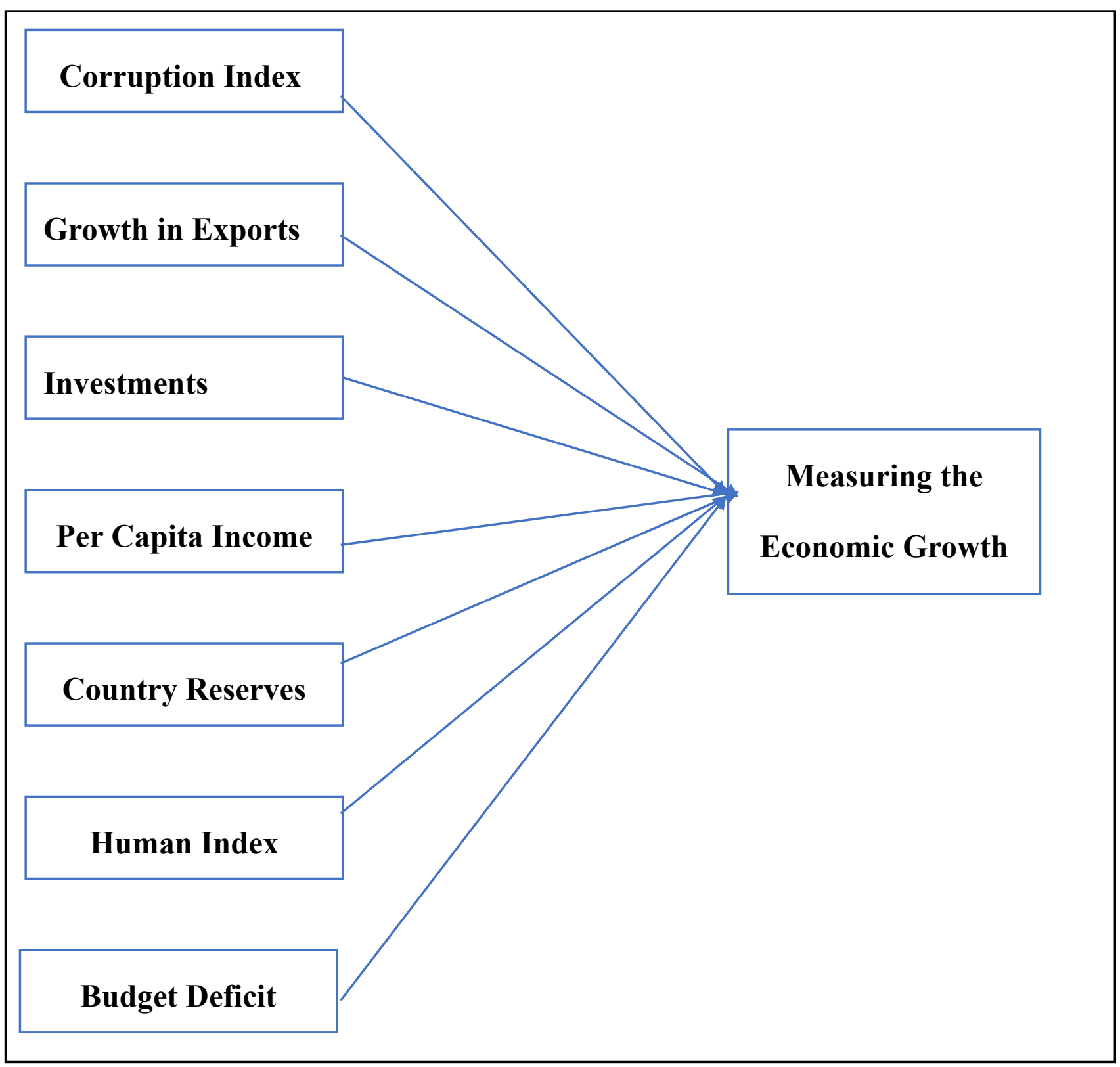

Figure 1A. Conceptual Framework to Measure Economic Growth in Afghanistan

\section{References}

Avnimelech, G., \& Zelekha, Y. (2015). The impact of corruption on entrepreneurship. Economics, 2-3, 981-993. https://doi.org/10.4018/978-1-4666-8468-3.ch053 
Boussalham, H. (2018). The Consequences of Corruption on economic growth in Mediterranean countries: Evidence from Panel data analysis. https://doi.org/10.20944/preprints201802.0065.v3

Buzdar, M. F., Janjua, S. Y., \& Khurshid, M. A. (2016) Customer-based brand equity and firms' performance in the telecom industry. International Journal of Services and Operations Management, 25(3). https://doi.org/10.1504/IJSOM.2016.079516

CIA-World Factbook. (2018) The World Factbook - Central Intelligence Agency, CIA. 4 Retrieved November, 2018, from https://www.cia.gov/library/PUBLICATIONS/the-world-factbook/geos/pk.html

Eiilm university (2018). Economic Development. Retrieved 17 October 2018, from http://www.eiilmuniversity.co.in/downloads/Economic_Development.pdf

Eray Basar (2012). Issues in Afghanistan Foreword to the Compendium. Civil-military fusion center, (February).

Farooq, M., (2019). Customer Experience Management: A Handbook to Acquire and Retain Valuable Customers. Cyberjaya: Kindle Direct Publishing (KDP). Retrieved from https://www.amazon.com/gp/product/B07MC8SJ4X/ref=dbs_a_def_rwt_bibl_vppi_i0

Farooq, M.et all. (2018). Impact of Digitalization on Holy Quran Readers; Experience and Expectations. https://doi.org/10.9790/0837-2307035967.

Farooq, M., \& Jabbar, Z. (2014). Role of Word of Mouth in building CBBE. Elixir Marketing Mgmt. 23(2014) 26443-26447. Retrieved from http://www.elixirpublishers.com/articles/1408768877_73 (2014) 26443-26447.pdf

Khalil-Ur-Rehman, F., \& Farooq, M. (2018). Deployment of Mobile Learning in Advanced Education Foundations. Global Journal of Human-Social Science Research, 18(6).

McCranie, K. D. et al. (2011). The Impacts of Corruption On Economic Development In Afghanistan: A Study Of the Effects Of Nepotism And Bribery. Journal of Strategic Studies, 34(2), 281-293. https://doi.org/10.1080/01402390.2011.569130

Mo, P. H. (2001). Corruption and economic growth. Journal of comparative economics, 29(1), 66-79. https://doi.org/10.1006/jcec. 2000.1703

Sarkar, H., \& Hasan, M. A. (2001). Impact of corruption on the efficiency of investment: Evidence from a cross-country analysis. Asia-Pacific Development Journal, 8(2), 111-116.

Tanning, L., \& Tanning, T. (2014). The Economic Crisis Lessons of Transportation Companies by Labour Productivity in Baltic and Central and Eastern Europe Countries. Journal of Behavioural Economics, Finance, Entrepreneurship, Accounting and Transport. Science and Education Publishing. USA, 2(4), 94-103. Retrieved 17 October, 2018, from http://www.sciepub.com/reference/74288 


\section{Macrothink}

\section{Copyright Disclaimer}

Copyright for this article is retained by the author(s), with first publication rights granted to the journal.

This is an open-access article distributed under the terms and conditions of the Creative Commons Attribution license (http://creativecommons.org/licenses/by/4.0/). 